\title{
Genome sequences and annotation of two urinary isolates of $E$. coli
}

\author{
Travis K. Price ${ }^{1}$, Arya Mehrtash², Laurynas Kalesinskas ${ }^{2,3}$, Kema Malki ${ }^{3}$, Evann E. Hilt ${ }^{1}$, Catherine Putonti ${ }^{2,3,4}$ \\ and Alan J. Wolfe ${ }^{1 *}$
}

\begin{abstract}
The genus Escherichia includes pathogens and commensals. Bladder infections (cystitis) result most often from colonization of the bladder by uropathogenic E. coli strains. In contrast, a poorly defined condition called asymptomatic bacteriuria results from colonization of the bladder with $E$. coli strains without symptoms. As part of an on-going attempt to identify and characterize the newly discovered female urinary microbiota, we report the genome sequences and annotation of two urinary isolates of E. coli: one (E78) was isolated from a female patient who self-reported cystitis; the other (E75) was isolated from a female patient who reported that she did not have symptoms of cystitis. Whereas strain E75 is most closely related to an avian extraintestinal pathogen, strain E78 is a member of a clade that includes extraintestinal strains often found in the human bladder. Both genomes are uncommonly rich in prophages.
\end{abstract}

Keywords: Enterobacteriaceae, Escherichia coli, UPEC, Urinary tract infection, Bladder, Lower urinary tract symptoms

\section{Introduction}

Clinicians typically equate the presence of bacteria in urine with infection, or, less commonly, an ill-defined phenomenon termed "asymptomatic bacteriuria." These and other existing concepts are based on the long-held "sterile urine" paradigm. Recently, however, bacterial communities (microbiota) have been discovered in the female bladder [1-9]. Thus, the "sterile urine" paradigm is no longer valid.

In an effort to provide a comprehensive view of the newly discovered female urinary microbiota, we have established an Enhanced Quantitative Urine Culture protocol. This enhanced culture protocol isolates bacteria from 75 to $90 \%$ of urine samples deemed 'no growth' by the standard clinical microbiology urine culture method $[4,7,10]$. We have begun to the sequence and annotate the genomes of these isolated bacteria.

Here, we report the full genome sequences and annotations of two of those bacteria, Escherichia coli strains E75 and E78 isolated from female patients pursuing

\footnotetext{
* Correspondence: awolfe@luc.edu

${ }^{1}$ Department of Microbiology and Immunology, Stritch School of Medicine, Health Sciences Division, Loyola University Chicago, 2160 South First Avenue, Maywood, IL 60153, USA

Full list of author information is available at the end of the article
}

urogynecologic clinical care. Strain E75 was isolated from a patient who thought that she did not have a urinary tract infection, while E78 was isolated from a patient who thought that she did. The strains were sub-cultured to purity and then identified as E. coli by Matrix-Assisted Laser Desorption/Ionization-Time-of-Flight Mass Spectrometry [10]. Strain E75 is most closely related to APEC O1, an avian extraintestinal pathogen. In contrast, strain E78 is a member of a clade that includes extraintestinal strains often associated with the human bladder, including uropathogenic strains UTI89 and J89 and asymptomatic bacteriuric strain ABU83972. Both genomes are uncommonly rich in prophages.

\section{Organism information Classification and features}

Escherichia coli is a non-sporulating, Gram-negative, rod shaped bacterium. It is a facultative anaerobe found commonly in the environment and the lower intestines of mammals and other endotherms. Extra-intestinal strains can colonize other organs, including the urinary bladder. Most E. coli strains are harmless constituents of the normal microbiota, but others cause disease. For example, uropathogenic E. coli is the major case of urinary tract infections in humans; other E. coli strains colonize 
the bladder without causing symptoms, a condition called asymptomatic bacteriuria.

Transmission electron microscopy images were generated for both E75 and E78 (Fig. 1). Cell pellets were fixed with $0.1 \%$ Ruthenium Red en bloc with sequential gluteraldehyde and osmium tetroxide fixation steps. These fixed samples were dehydrated with Ethanol and embedded in Resin. Ultrathin sections of $80 \mathrm{~nm}$ were mounted on copper grids, post-stained with uranyl acetate and lead citrate and observed in a Hitachi H-600 transmission electron microscope at $75 \mathrm{kV}$. Films were taken, negatives developed and scanned via a Microtek i800 film scanner. PhotoShop was used to convert negatives to positive images and adjust for brightness and contrast. The transmission electron micrographs revealed the typical $E$. coli rod-shape morphology. Strain E75 tended to possess electron poor intracellular inclusions (Fig. 1b, black arrow). The general features of $E$. coli strains E75 and E78 are presented in Table 1.

E. coli strains E75 and E78 were isolated from patients who sought clinical care at Loyola University Medical Center's Female Pelvic Medicine and Reconstructive Surgery center in September 2014. Patients were asked the question: Do you feel that you have a urinary tract infection? E75 was isolated from a patient who answered 'no', whereas E78 was isolated from a patient who answered 'yes.' Both patients were white, post-menopausal women seeking care for Pelvic Organ Prolapse. Neither patient was taking antibiotics; both were using daily vaginal estrogen supplement. The UTI Symptoms Assessment Questionnaire was used to characterize the degree of severity and bother of the patients' symptoms [11]. Both E. coli strains were identified at $>100,000$ colony forming units per milliliter, using an Expanded Spectrum version of the Enhanced Quantitative Urine Culture protocol [10]. After they were sub-cultured to purity,
Matrix-Assisted Laser Desorption/Ionization-Time-ofFlight Mass Spectrometry was used to confidently identify them as E. coli. For E75, the identification score was 2.530; for E78, the score was 2.265. No other microbes were detected in the urine sample containing strain E75. In the urine sample containing strain E78, Alloscardovia omnicolens (10 colony forming units per milliliter) and Lactobacillus rhamnosus (10 colony forming units per milliliter) were also detected.

Figure 2 shows a phylogenetic tree of the 16S rRNA sequences. 16S rRNA gene sequences include Yersinia enterocolitica (NR_104903), E. coli IAI39 (NC_011750), E. coli O157:H7 str. Sakai (NR_074891), E. coli K-12 substr. MG1655 (NR_102804), E. coli O157:H7 str. EDL933 (AE005174), E. coli CFT073 (AE014075), E. coli VR50 (CP011134), E. coli UMN026 (NC_011751), E. coli RRL-36 (JQ398845), E. coli NBRC 102203 (NR_114042), E. coli U 5/41 (NR_024570), E. coli B str. REL606 (CP000819), E. coli O104:H4 str. 2011C-3493 (NC_018658), E. coli XA04 (KR080744), E. coli APEC O1 (CP000468), E. coli E75, E. coli E78, E. coli $\mathrm{J} 96$ (ALIN02000018), E. coli TOP379 149 (AOQB01000139), E. coli UMEA 3314-1 (AWDE010000004), E. coli UTI89 (CP000243), E. coli ABU 83972 (CP001671), and E. coli UM146 (CP002167). E. coli genome sequences typically include seven copies [12].

\section{Genome sequencing information} Genome project history

The sequencing and quality assurance was performed at the Loyola Genome Facility at Loyola University Chicago, Maywood, IL, USA. The assemblies and finishing were done at the Lakeshore Campus of Loyola University Chicago, Chicago, IL, USA. Functional annotation was produced by the RAST service [13] and in-house scripts for COG classification [14]. Table 2 presents the project

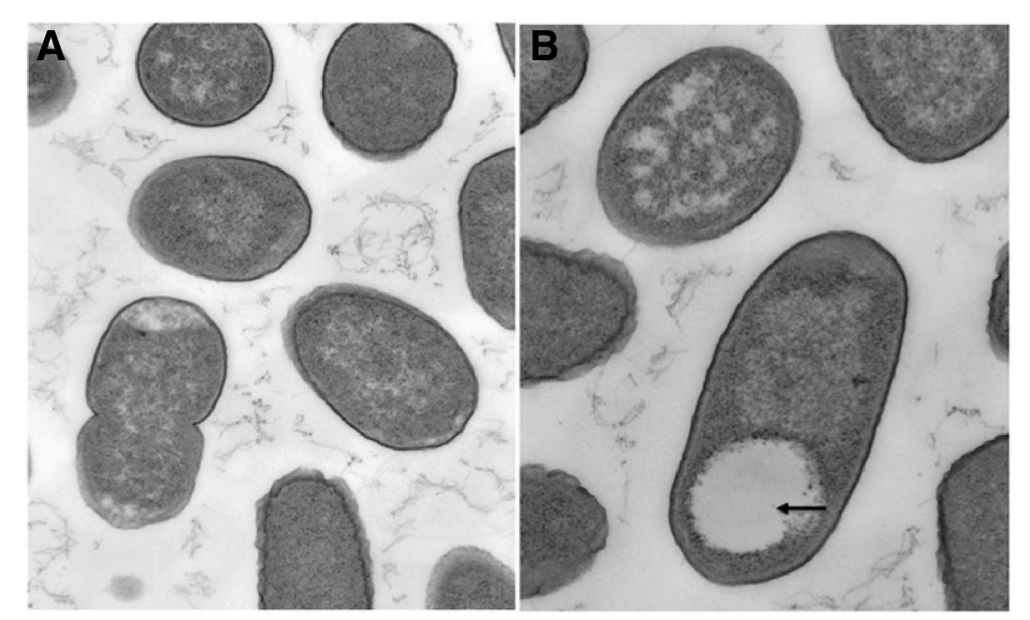

Fig. 1 Transmission Electron Microscopy Images of E78 (a) and E75 (b). E75 tended to have electron poor intracellular inclusions (black arrow) 
Table 1 Classification and general features of E. coli strains E75 and E78

\begin{tabular}{|c|c|c|c|}
\hline MIGS ID & Property & Term & Evidence code $\mathrm{e}^{\mathrm{a}}$ \\
\hline & Classification & Domain Bacteria & TAS [31] \\
\hline & & Phylum Proteobacteria & TAS [32] \\
\hline & & Class Gammaproteobacteria & $\operatorname{TAS}[33,34]$ \\
\hline & & Order Enterobacteriales & TAS [35] \\
\hline & & Family Enterobacteriaceae & $\operatorname{TAS}[36,37]$ \\
\hline & & Genus Escherichia & $\operatorname{TAS}[37,38]$ \\
\hline & & Species Escherichia coli & $\operatorname{TAS}[37,38]$ \\
\hline & & Strain: E75 and E78 & \\
\hline & Gram stain & Negative & TAS [39] \\
\hline & Cell shape & Rod & TAS [39] \\
\hline & Motility & Motile & TAS [39] \\
\hline & Sporulation & Non-spore former & NAS \\
\hline & Temperature range & $7-46^{\circ} \mathrm{C}$ & NAS \\
\hline & Optimum temperature & $37^{\circ} \mathrm{C}$ & IDA \\
\hline & pH range; Optimum & $4.4-9.0 ; 6-7$ & IDA \\
\hline & Carbon source & Not determined, strains grown in complex medium & NAS \\
\hline MIGS-6 & Habitat & Human female bladder & NAS \\
\hline MIGS-6.3 & Salinity & $0.5 \%(w / v)$ & NAS \\
\hline MIGS-22 & Oxygen requirement & Facultative anaerobe & TAS [39] \\
\hline MIGS-15 & Biotic relationship & Human specimen & NAS \\
\hline MIGS-14 & Pathogenicity & $\begin{array}{l}\text { Non-pathogen (E75) } \\
\text { Suspected pathogen (E78) }\end{array}$ & NAS \\
\hline MIGS-4 & Geographic location & Maywood, IL USA & NAS \\
\hline MIGS-5 & Sample collection & E75 (9/14/2014); E78 (9/25/2014) & \\
\hline MIGS-4.1 & Latitude & $41.8811^{\circ} \mathrm{N}$ & \\
\hline MIGS-4.2 & Longitude & $87.8433^{\circ} \mathrm{W}$ & \\
\hline MIGS-4.4 & Altitude & $623 \mathrm{ft}$ & \\
\hline
\end{tabular}

${ }^{a}$ Evidence codes_IDA: Inferred from Direct Assay; TAS: Traceable Author Statement (i.e., a direct report exists in the literature); NAS: Non-traceable Author Statement (i.e., not directly observed for the living, isolated sample, but based on a generally accepted property for the species, or anecdotal evidence). These evidence codes are from the Gene Ontology project [40]

information and its association with MIGSversion2.0compliance [15].

\section{Growth conditions and genomic DNA preparation}

E. coli strains E75 and E78 were isolated from transurethral catheterized urine specimens of adult women with urinary symptoms [10] using a Expanded Spectrum version of the previously described Enhanced Quantitative Urine Culture protocol [4]. Three urine volumes $(1 \mu \mathrm{L}, 10 \mu \mathrm{L}$, and $100 \mu \mathrm{L})$ of each urine sample was spread quantitatively (i.e., pinwheel streak) onto $\mathrm{t} 5 \%$ sheep blood (BD BBL ${ }^{\text {Tu }}$ Prepared Plated Media, Cockeysville, MD), Chocolate, and Colistin Naladixic Acid agars (BD BBL ${ }^{\mathrm{Tu}}$ Prepared Plated Media) and incubated in $5 \%$ $\mathrm{CO}_{2}$ at $35{ }^{\circ} \mathrm{C}$ for $48 \mathrm{~h} ; 5 \%$ sheep blood and MacConkey (BD BBL ${ }^{\text {put }}$ Prepared Plated Media) agars incubated aerobically at $35{ }^{\circ} \mathrm{C}$ for $48 \mathrm{~h}$; two CDC Anaerobic $5 \%$ sheep blood agars (BD BBL ${ }^{\mathrm{m}}$ Prepared Plated Media) incubated in either Microaerophilic Campy gas mixture $\left(5 \% \mathrm{O}_{2}\right.$, $10 \% \mathrm{CO}_{2}, 85 \% \mathrm{~N}$ ), or anaerobically at $35{ }^{\circ} \mathrm{C}$ for $48 \mathrm{~h}$. All agars were documented for growth (i.e., for morphologies and colony forming units per milliliter) at 24 and $48 \mathrm{~h}$. Each distinct colony morphology was sub-cultured at $48 \mathrm{~h}$ to obtain pure culture for microbial identification.

Microbial identification was determined using a Matrix-Assisted Laser Desorption/Ionization-Time-ofFlight Mass Spectrometer (Bruker Daltonics, Billerica, MA) as described [4]. Pure cultures were stored at $-80{ }^{\circ} \mathrm{C}$ in a $2 \mathrm{ml}$ CryoSaver Brucella Broth with $10 \%$ Glycerol, no beads, Cryovial, for preservation (Hardy Diagnostics). For genome extraction and sequencing, the preserved pure culture isolates were grown on $5 \%$ sheep blood agar under aerobic conditions at $35{ }^{\circ} \mathrm{C}$ for $24 \mathrm{~h}$. 


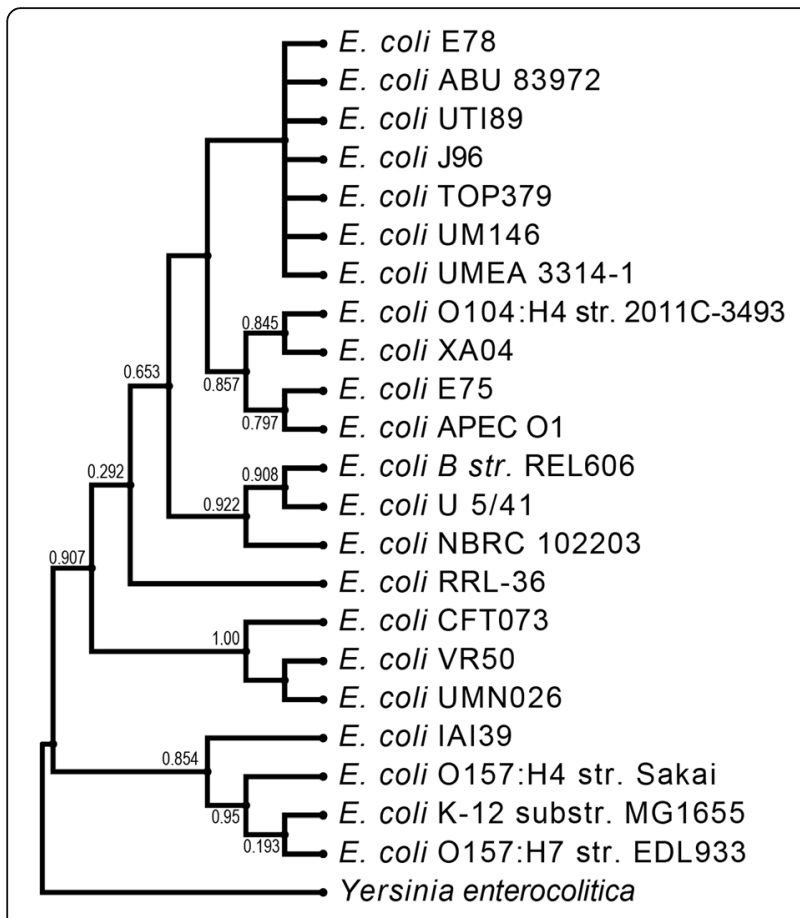

Fig. 2 Phylogenetic tree based on $16 \mathrm{~S}$ rRNA sequences. The alignment length was $1189 \mathrm{bp}$. Sequences were retrieved from NCBI and aligned using Muscle. The tree was generated by FastTree using the GTR model. Support values are shown for branches leading to the placement of the two bladder isolates presented here

Genomic DNA extraction was performed using a phenol-chloroform extraction protocol. Briefly, cells were resuspended in $0.5 \mathrm{~mL}$ DNA Extraction Buffer $(20 \mathrm{mM}$ Tris-Cl, 2 mM EDTA, 1.2 \% Triton X-100, pH 8) followed by addition of $50 \mathrm{uL}$ Lysozyme $(20 \mathrm{mg} / \mathrm{mL}), 30 \mathrm{uL}$ Mutanolysin, and $5 \mathrm{uL}$ RNase $(10 \mathrm{mg} / \mathrm{mL})$. After a $1 \mathrm{~h}$ incubation at $37{ }^{\circ} \mathrm{C}, 80 \mathrm{uL} 10 \% \mathrm{SDS}$, and $20 \mathrm{uL}$ Proteinase $\mathrm{K}$ were added followed by a $2 \mathrm{~h}$ incubation at $55^{\circ} \mathrm{C}$. 210uL of $6 \mathrm{M}$ $\mathrm{NaCl}$ and $700 \mathrm{uL}$ phenol-chloroform were then added. After a 30-min incubation with rotation, the solutions were centrifuged at 13,500 RPM for $10 \mathrm{~min}$, and the aqueous phase was extracted. An equivalent volume of Isopropanol was then added, and solution was centrifuged at 13,500 RPM for $10 \mathrm{~min}$ after a $10-\mathrm{min}$ incubation. The supernatant was decanted and the DNA pellet was precipitated using 600uL 70 \% Ethanol. Following ethanol evaporation, the DNA pellet was resuspended in Tris-EDTA and stored at $-20{ }^{\circ} \mathrm{C}$.

\section{Genome sequencing and assembly}

DNA samples were diluted in water to a concentration of $0.2 \mathrm{ng} / \mathrm{ul}$ as measured by a fluorometric-based method (Life Technologies, Carlsbad, CA) and 5 ul was used to obtain a total of $1 \mathrm{ng}$ of input DNA. Library preparation was performed using the Nextera XT DNA Library Preparation Kit (Illumina, San Diego, CA) according to manufacturer's instructions. The isolates were barcoded, pooled and each isolate was sequenced twice, on two separate runs, using the Illumina MiSeq platform and the MiSeq Reagent Kit v2 (300-cycles) to produce 150 bp paired-end reads. Sequencing reads were parsed into individual folders according to the respective barcodes.

Sequence assembly was conducted using Velvet [16] (Table 2). The tool VelvetOptimiser was used to determine the best hash length; 99 was used in the two assemblies performed here. The scaffolding software SSPACE [17] was utilized for scaffold finishing. The genome of strain E75 was assembled into 463 contigs. The genome of strain E78 was assembled into 62 contigs. To confirm that the contigs were Enterobacteriaceae (i.e. not the result of contamination), each contig was

Table 2 Project information

\begin{tabular}{|c|c|c|c|}
\hline MIGS ID & Property & E75 Term & E78 Term \\
\hline MIGS 31 & Finishing quality & High quality draft & High quality draft \\
\hline MIGS-28 & Libraries used & Paired-end library of 150 bp & Paired-end library of $150 \mathrm{bp}$ \\
\hline MIGS 29 & Sequencing platforms & Illumina MiSeq & Illumina MiSeq \\
\hline MIGS 31.2 & Fold coverage & $51-431 \times$ & $53-30724 x$ \\
\hline MIGS 30 & Assemblers & Velvet & Velvet \\
\hline \multirow[t]{6}{*}{ MIGS 32} & Gene calling method & GLIMMER & GLIMMER \\
\hline & Locus tag & & \\
\hline & Genbank ID & LXGO00000000 & LXQH00000000 \\
\hline & GenBank Date of Release & May 9, 2016 & May 9, 2016 \\
\hline & GOLD ID & & \\
\hline & BIOPROJECT & PRJNA316969 & PRJNA316969 \\
\hline \multirow[t]{2}{*}{ MIGS 13} & Source Material Identifier & & \\
\hline & Project relevance & Human commensal & Human pathogen \\
\hline
\end{tabular}


Table 3 Summary of genomes: two chromosomes and two plasmids

\begin{tabular}{llll}
\hline Label & Size (bp) & Topology & INSDC identifier \\
\hline Chromosome E75 & $5,032,328$ & Circular & LXGO00000000 \\
Chromosome E78 & $5,021,201$ & Circular & LXQH00000000 \\
Plasmid pE78.1 & 4083 & Circular & LXQH00000000 \\
Plasmid pE78.2 & 2113 & Circular & LXQH00000000 \\
\hline
\end{tabular}

BLASTed locally against all publicly available bacterial genomes (obtained from NCBI). Coverage across all contigs was on average 50.95-431.17X (for E75) and 52.59-30,723.61X (for E78). The high coverage observed within the E78 sequencing is the result of two contigs, one $4083 \mathrm{bp}$ in length (coverage 72,734X) and the other $2113 \mathrm{bp}$ in length $(99,530 \mathrm{X})$. Assembly was repeated using the SPAdes assembler [18], given its recent success in producing full plasmid sequences [19]. Two plasmids were identified by the SPAdes assembler with high coverage. Querying these two contigs against the GenBank nr/nt database revealed sequence homology to the annotated E. coli plasmids p2PCN033 (GenBank: CP006634) and pVR50G (GenBank: CP011141) (among other E. coli plasmids), respectively. These two plasmids are listed in Table 3 as Plasmid pE78.1 and Plasmid pE78.2, respectively. All 62 E78 contigs were also assessed for putative plasmid sequences using PlasmidFinder [20]. While PlasmidFinder recognized pE78.2, it did not detect pE78.1. The complete genome of the E78 chromosome is thus represented within 60 contigs (mean coverage $272 \times$ ).

\section{Genome annotation}

Genes were identified using GLIMMER using the g3from-scratch.csh script included in the package [21] The predicted CDSs were translated using the transeq script within the EMBOSS suite [22]. rRNA genes were identified by RNAmmer [23] using the parameter set to identify bacterial rRNA sequences. The program tRNA-Scan [24] identified tRNA sequences, using the parameter for bacterial tRNAs. Trans-membrane proteins were identified using TMHMM with standard parameters [25]. SignalP [26] predicted signal peptides. All CDSs were queried (blastp) locally against the COG sequence dataset ([14]) and assigned based upon their sequence homologies. CRISPR elements were detected through CRISPR-db [27]. Genes with Pfam domains were ascertained via searches of the Pfam database (E-value threshold 1.0) [28].

\section{Genome properties}

Tables 4 and 5 include the summaries of the properties and statistics of each genome. Sequencing of the E78 isolate identified two plasmids (Table 3); the E75 isolate did not contain any identifiable plasmid sequences. The E75 and E78 chromosomes are similar in length and GC content: E75 is 5,032,328 bp (GC content 50.4\%), while E78 is 5,021,201 bp (GC content $50.3 \%$ ). The genomes for E75 and E78 are predicted to include 4587 and 4743

Table 4 Genome statistics

\begin{tabular}{|c|c|c|c|c|}
\hline \multirow{2}{*}{$\begin{array}{l}\text { Strain } \\
\text { Attribute }\end{array}$} & \multicolumn{2}{|l|}{ E75 } & \multicolumn{2}{|l|}{ E78 } \\
\hline & Value & $\overline{\%}$ of Total ${ }^{\mathrm{a}}$ & Value & $\%$ of Total ${ }^{a}$ \\
\hline Genome size (bp) & $5,032,328$ & 100.00 & $5,021,201$ & 100.00 \\
\hline DNA coding (bp) & $4,466,253$ & 88.75 & $4,348,152$ & 86.60 \\
\hline DNA G + C (bp) & $2,537,751$ & 50.43 & $2,525,290$ & 50.29 \\
\hline DNA scaffolds & 463 & na & 60 & na \\
\hline Total genes & 4666 & 100.00 & 4839 & 100.00 \\
\hline Protein coding genes & 4581 & 98.18 & 4743 & 98.02 \\
\hline RNA genes & 85 & 1.82 & 96 & 1.98 \\
\hline Pseudo genes & 0 & 0 & 0 & 0 \\
\hline Genes in internal clusters & na & na & na & na \\
\hline Genes with function prediction & 3290 & 70.51 & 3401 & 70.28 \\
\hline Genes assigned to COGs & 3496 & 74.92 & 3603 & 74.46 \\
\hline Genes with Pfam domains & 2067 & 44.30 & 2233 & 46.15 \\
\hline Genes with signal peptides & 361 & 7.74 & 374 & 7.73 \\
\hline Genes with transmembrane helices & 1083 & 23.21 & 1114 & 23.02 \\
\hline CRISPR repeats & 6 & & 5 & \\
\hline
\end{tabular}

${ }^{a}$ The total is based on either the size of the genome in base pairs or the total number of protein coding genes in the annotated genome 
Table 5 Number of genes associated with general COG functional categories

\begin{tabular}{|c|c|c|c|c|c|}
\hline \multirow{2}{*}{$\begin{array}{l}\text { Strain } \\
\text { Code }\end{array}$} & \multicolumn{2}{|l|}{ E75 } & \multicolumn{2}{|l|}{ E78 } & \multirow[b]{2}{*}{ Description } \\
\hline & Value & \%age & Value & \%age & \\
\hline J & 237 & 5.16 & 240 & 5.06 & Translation, ribosomal structure and biogenesis \\
\hline A & 2 & 0.04 & 2 & 0.04 & RNA processing and modification \\
\hline K & 242 & 5.28 & 258 & 5.44 & Transcription \\
\hline L & 151 & 3.29 & 152 & 3.21 & Replication, recombination and repair \\
\hline B & 0 & 0 & 0 & 0 & Chromatin structure and dynamics \\
\hline $\mathrm{D}$ & 44 & 0.96 & 43 & 0.91 & Cell cycle control, Cell division, chromosome partitioning \\
\hline V & 85 & 1.85 & 82 & 1.73 & Defense mechanisms \\
\hline T & 158 & 3.45 & 160 & 3.37 & Signal transduction mechanisms \\
\hline M & 238 & 5.19 & 241 & 5.05 & Cell wall/membrane biogenesis \\
\hline N & 89 & 1.94 & 95 & 2.00 & Cell motility \\
\hline$U$ & 52 & 1.13 & 50 & 1.05 & Intracellular trafficking and secretion \\
\hline O & 149 & 3.25 & 149 & 3.14 & Posttranslational modification, protein turnover, chaperones \\
\hline C & 266 & 5.80 & 278 & 5.86 & Energy production and conversion \\
\hline G & 366 & 7.98 & 386 & 8.14 & Carbohydrate transport and metabolism \\
\hline E & 336 & 7.33 & 338 & 7.13 & Amino acid transport and metabolism \\
\hline $\mathrm{F}$ & 104 & 2.27 & 102 & 2.15 & Nucleotide transport and metabolism \\
\hline $\mathrm{H}$ & 167 & 3.64 & 169 & 3.56 & Coenzyme transport and metabolism \\
\hline । & 115 & 2.51 & 118 & 2.49 & Lipid transport and metabolism \\
\hline P & 213 & 4.64 & 212 & 4.47 & Inorganic ion transport and metabolism \\
\hline Q & 53 & 1.16 & 53 & 1.12 & Secondary metabolites biosynthesis, transport and catabolism \\
\hline $\mathrm{R}$ & 173 & 3.77 & 178 & 3.75 & General function prediction only \\
\hline S & 206 & 4.50 & 202 & 4.26 & Function unknown \\
\hline- & 1085 & 23.69 & 1140 & 24.04 & Not in COGs \\
\hline
\end{tabular}

The total is based on the total number of protein coding genes in the genome

protein coding genes, respectively. A similar coding density is observed within the two genomes. The 85 RNA genes identified within the E75 genome include 78 tRNAs and 7 rRNAs. The E78 genome encodes for more RNA genes: 83 tRNAs and 13 rRNAs. The scaffolds of E75 and E78 are only annotated as having a single 16S rRNA gene, an underestimation due to recognized challenges of assembling sequences containing genes with multiple copies such as the rRNA genes [29] Thus, we fully expect that the E75 and E78 genomes harbor rRNA gene numbers on par with the genus.

\section{Insights from the genome sequence}

Although E75 was isolated from a woman who reported that she did not have symptoms of cystitis, its genome encodes proteins associated with $E$. coli pathogenesis, including the P pilus, RTX toxin, and $\alpha$-fimbriae. These genes were not found in E78. While the E75 strain did not include plasmid sequences, genome sequencing of the E78 isolate contained two. Plasmid pE78.2 was nearly identical (one mismatch) to the E. coli plasmid
pVR50G, collected from urine obtained from an individual with asymptomatic bacteriuria [30].

Both genomes included a number of prophages. Each prophage sequence within the genomes was BLASTed (blastx) to the $\mathrm{nr} / \mathrm{nt}$ database revealing numerous hits to phage sequences annotated as infecting Escherichia spp. Annotations within the genomes of the temperate phages Lambda and P4 were identified most frequently within the E75 and E78 genomes, respectively. Table 6 lists the statistics of this search. The vast majority of the hits were to phages annotated as infectious for

Table 6 Predicted sequences of phage origin and putative origin

\begin{tabular}{|c|c|c|}
\hline & E75 & E78 \\
\hline $\begin{array}{l}\text { Number of predicted phage } \\
\text { CDSs }\end{array}$ & 112 & 112 \\
\hline $\begin{array}{l}\text { Exhibit no sequence homology } \\
\text { to GenBank }\end{array}$ & 4 & 10 \\
\hline Species with most hits (\# hits) & $\begin{array}{l}\text { Enterobacteria phage } \\
\text { lambda (19) }\end{array}$ & $\begin{array}{l}\text { Bacteriophage } \\
\text { P4 (10) }\end{array}$ \\
\hline
\end{tabular}

Sequence homologies determined via blastx 
Escherichia, Salmonella, and/or Shigella spp. Nevertheless, prophage sequences for both temperate as well as lytic phages were identified. The abundance of prophage sequences within these two genomes exceeds that previously identified in E. coli genomes.

\section{Conclusions}

The genome of E75, isolated from a woman who reported no symptoms of cystitis, is more closely related to the avian extraintestinal pathogen APEC 01. The genome of E75, isolated from a woman who reported cystitis symptoms, resides in a clade populated by human extra-intestinal strains that are either uropathogenic or asymptomatic bacteriuric. Both genomes contain an unusually large number of prophage sequences.

\section{Acknowledgements}

We would like to acknowledge Female Pelvic Medicine \& Reconstructive Surgery at Loyola University Medical Center for their help in the patient recruitment and sample collection that led to isolation of these strains, Dr. Doerte Lehmann for aiding in the TEM sample preparation protocol, and Linda Fox from the Core Imaging Facility at Loyola University Chicago for obtaining the TEM images. We also acknowledge Gina Kuffel and Dr. Michael Zilliox for sequencing the genomes. AJW and CP are supported by Loyola University Chicago's Multidisciplinary Research Award. This work was also partially funded by the NSF (1149387 to CP) and the NIH (R21DK097435$01 \mathrm{~A} 1$ to $\mathrm{AJW}$ ).

\section{Authors' contributions}

TKP conceived the project, isolated the bacteria, identified them by MALDI-TOF, and prepared them for sequencing. AM, KM, LK, and CP analysed the sequence data. EEH attained the TEM images. AJW conceived the project and oversaw its progress. AJW and CP wrote the manuscript. All authors read and edited the manuscript. All authors read and approved the final manuscript.

\section{Competing interests}

The authors have no competing interests to report.

\section{Author details}

'Department of Microbiology and Immunology, Stritch School of Medicine, Health Sciences Division, Loyola University Chicago, 2160 South First Avenue, Maywood, IL 60153, USA. ${ }^{2}$ Bioinformatics Program, Loyola University Chicago, Chicago, IL, USA. ${ }^{3}$ Department of Biology, Loyola University Chicago, Chicago, IL, USA. ${ }^{4}$ Department of Computer Science, Loyola University Chicago, Chicago, IL, USA.

Received: 13 May 2016 Accepted: 4 October 2016

Published online: 12 October 2016

\section{References}

1. Brubaker L, Nager C, Richter H, Visco A, Nygaard I, Barber M, Schaffer J, Meikle $S$, Wallace $D$, Shibata N, Wolfe A. Urinary bacteria in adult women with urgency urinary incontinence. Int Urogynecol J. 2014;25(9):1179-84.

2. Nienhouse V, Gao X, Dong Q, Nelson DE, Toh E, McKinley K, Schreckenberger P, Shibata N, Fok CS, Mueller ER, et al. Interplay between bladder microbiota and urinary antimicrobial peptides: mechanisms for human urinary tract infection risk and symptom severity. PLoS One. 2014;9: e114185.

3. Fouts DE, Pieper R, Szpakowski S, Pohl H, Knoblach S, Suh MJ, Huang ST, Ljungberg I, Sprague BM, Lucas SK, et al. Integrated next-generation sequencing of $165 \mathrm{rDNA}$ and metaproteomics differentiate the healthy urine microbiome from asymptomatic bacteriuria in neuropathic bladder associated with spinal cord injury. J Transl Med. 2012;10:174.

4. Hilt EE, McKinley K, Pearce MM, Rosenfeld AB, Zilliox MJ, Mueller ER, Brubaker L, Gai X, Wolfe AJ, Schreckenberger PC. Urine is not sterile: use of enhanced urine culture techniques to detect resident bacterial flora in the adult female bladder. J Clin Microbiol. 2014;52:871-6.
5. Khasriya R, Sathiananthamoorthy S, Ismail S, Kelsey M, Wilson M, Rohn JL, Malone-Lee J. Spectrum of bacterial colonization associated with urothelial cells from patients with chronic lower urinary tract symptoms. J Clin Microbiol. 2013:51:2054-62.

6. Lewis DA, Brown R, Williams J, White P, Jacobson SK, Marchesi JR, Drake MJ. The human urinary microbiome; bacterial DNA in voided urine of asymptomatic adults. Front Cell Infect Microbiol. 2013;3:41.

7. Pearce MM, Hilt EE, Rosenfeld AB, Zilliox MJ, Thomas-White K, Fok C Kliethermes S, Schreckenberger P, Brubaker L, Gai X, Wolfe AJ. The Female Urinary Microbiome: A Comparison of Women With and Without Urgency Urinary Incontinence. mBio. 2014;5(4). doi:10.1128/mBio.01283-14.

8. Siddiqui H, Nederbragt AJ, Lagesen K, Jeansson SL, Jakobsen KS. Assessing diversity of the female urine microbiota by high throughput sequencing of 16S rDNA amplicons. BMC Microbiol. 2011;11:244.

9. Wolfe AJ, Toh E, Shibata N, Rong R, Kenton K, Fitzgerald M, Mueller ER, Schreckenberger P, Dong Q, Nelson DE, Brubaker L. Evidence of uncultivated bacteria in the adult female bladder. J Clin Microbiol. 2012;50:1376-83.

10. Price TK, Dune T, Hilt EE, Thomas-White K, Kliethermes S, Brincat C, Brubaker L, Wolfe AJ, Mueller ER, Schreckenberger P. The Clinical Urine Culture: Enhanced Techniques Improve Detection of Clinically Relevant Microorganisms. J Clin Microbiol. 2016;54(5):1216-22.

11. Clayson D, Wild D, Doll H, Keating K, Gondek K. Validation of a patientadministered questionnaire to measure the severity and bothersomeness of lower urinary tract symptoms in uncomplicated urinary tract infection (UTI): the UTI Symptom Assessment questionnaire. BJU Int. 2005;96:350-9.

12. Stoddard SF, Smith BJ, Hein R, Roller BR, Schmidt TM. rrnDB: improved tools for interpreting rRNA gene abundance in bacteria and archaea and a new foundation for future development. Nucleic Acids Res. 2015;43:D593-598.

13. Aziz RK, Bartels D, Best AA, Dejongh M, Disz T, Edwards RA, Formsma K, Gerdes S, Glass EM, Kubal M, et al. The RAST Server: rapid annotations using subsystems technology. BMC Genomics. 2008;9:75.

14. Galperin MY, Makarova KS, Wolf YI, Koonin EV. Expanded microbial genome coverage and improved protein family annotation in the COG database. Nucleic Acids Res. 2015:43:D261-269.

15. Field D, Garrity G, Gray T, Morrison N, Selengut J, Sterk P, Tatusova T, Thomson N, Allen MJ, Angiuoli SV, et al. The minimum information about a genome sequence (MIGS) specification. Nat Biotechnol. 2008;26:541-7.

16. Zerbino DR. Using the Velvet de novo assembler for short-read sequencing technologies. Curr Protoc Bioinformatics. 2010;Chapter 11:Unit 11.15.

17. Boetzer M, Henkel CV, Jansen HJ, Butler D, Pirovano W. Scaffolding preassembled contigs using SSPACE. Bioinformatics. 2011;27:578-9.

18. Bankevich A, Nurk S, Antipov D, Gurevich AA, Dvorkin M, Kulikov AS, Lesin VM, Nikolenko SI, Pham S, Prjibelski AD, et al. SPAdes: a new genome assembly algorithm and its applications to single-cell sequencing. J Comput Biol. 2012:19:455-77.

19. Antipov D, Hartwick N, Shen M, Raiko M, Lapidus A, Pevzner P. plasmidSPAdes: Assembling Plasmids from Whole Genome Sequencing Data. bioRxiv. 2016. [Epub ahead of print].

20. Carattoli A, Zankari E, Garcia-Fernandez A, Voldby Larsen M, Lund O, Villa L, Moller Aarestrup F, Hasman H. In silico detection and typing of plasmids using PlasmidFinder and plasmid multilocus sequence typing. Antimicrob Agents Chemother. 2014;58:3895-903.

21. Delcher AL, Bratke KA, Powers EC, Salzberg SL. Identifying bacterial genes and endosymbiont DNA with Glimmer. Bioinformatics. 2007;23:673-9.

22. Li W, Cowley A, Uludag M, Gur T, McWilliam H, Squizzato S, Park YM, Buso $\mathrm{N}$, Lopez R. The EMBL-EBI bioinformatics web and programmatic tools framework. Nucleic Acids Res. 2015;43:W580-584.

23. Lagesen K, Hallin P, Rodland EA, Staerfeldt HH, Rognes T, Ussery DW. RNAmmer: consistent and rapid annotation of ribosomal RNA genes. Nucleic Acids Res. 2007;35:3100-8.

24. Schattner P, Brooks AN, Lowe TM. The tRNAscan-SE, snoscan and snoGPS web servers for the detection of tRNAs and snoRNAs. Nucleic Acids Res. 2005;33:W686-689

25. Krogh A, Larsson B, von Heijne G, Sonnhammer EL. Predicting transmembrane protein topology with a hidden Markov model: application to complete genomes. J Mol Biol. 2001;305:567-80.

26. Petersen TN, Brunak S, von Heijne G, Nielsen H. SignalP 4.0: discriminating signal peptides from transmembrane regions. Nat Methods. 2011;8:785-6.

27. Grissa I, Vergnaud G, Pourcel C. CRISPRFinder: a web tool to identify clustered regularly interspaced short palindromic repeats. Nucleic Acids Res. 2007;35:W52-57. 
28. Finn RD, Coggill P, Eberhardt RY, Eddy SR, Mistry J, Mitchell AL, Potter SC, Punta M, Qureshi M, Sangrador-Vegas A, et al. The Pfam protein families database: towards a more sustainable future. Nucleic Acids Res. 2016;44: D279-285.

29. Denton JF, Lugo-Martinez J, Tucker AE, Schrider DR, Warren WC, Hahn MW. Extensive error in the number of genes inferred from draft genome assemblies. PLoS Comput Biol. 2014;10(12):e1003998.

30. Beatson SA, Ben Zakour NL, Totsika M, Forde BM, Watts RE, Mabbett AN, Szubert JM, Sarkar S, Phan MD, Peters KM, et al. Molecular analysis of asymptomatic bacteriuria Escherichia coli strain VR50 reveals adaptation to the urinary tract by gene acquisition. Infect Immun. 2015;83:1749-64.

31. Woese CR, Kandler O, Wheelis ML. Towards a natural system of organisms: proposal for the domains Archaea, Bacteria, and Eucarya. Proc Natl Acad Sci U S A. 1990;87:4576-9.

32. Garrity G, Bell J, Lillburn T. Phylum XIV. Proteobacteria phyl nov. In: Brenner D, Krieg N, Stanley J, Garrity G, editors. Bergey's Manual of Systematic Bacteriology Second edition, Volume 2 (The Proteobacteria part B The Gammaproteobacteria). New York: Springer; 2005.

33. Garrity G, Bell J, Lilburn T. Class III. Gammaproteobacteria class. nov. In: Garrity G, Brenner D, Krieg N, Staley J, editors. Bergey's Manual of Systematic Bacteriology, Second Edition, Volume 2, Part B. New York: Springer; 2005.

34. List Editor: Validation of publication of new names and new combinations previously effectively published outside the IJSEM. List no. 106. Int J Syst Evol Microbiol. 2005;55:2235.

35. Garrity GM, Holt JG. Taxonomic outline of the archaea and bacteria. Bergey's Man Syst Bacteriol. 2001;1:155. <<Enterobacteriales.

36. Rahn O. New principles for the classification of bacteria. Zentralblatt für Bakteriologie, Parasitenkunde, Infektionskrankheiten und Hygiene. Abteilung II. 1937;96:273-86

37. Skerman VBD, McGowan V, Sneath PHA. Approved lists of bacterial Names. Int J Syst Bacteriol. 1920;30:225.

38. Castellani A, Chalmers AJ: Genus Escherichia Castellani and Chalmers, 1918. Man Trop Med. 1919;941:607-24.

39. Welch R. The genus Escherichia. In: The Prokaryotes. New York: Springer; 2006. p. 60-71.

40. Ashburner M, Ball CA, Blake JA, Botstein D, Butler H, Cherry JM, Davis AP, Dolinski K, Dwight SS, Eppig JT, et al. Gene ontology: tool for the unification of biology. The Gene Ontology Consortium. Nat Genet. 2000;25:25-9.

\section{Submit your next manuscript to BioMed Central and we will help you at every step:}

- We accept pre-submission inquiries

- Our selector tool helps you to find the most relevant journal

- We provide round the clock customer support

- Convenient online submission

- Thorough peer review

- Inclusion in PubMed and all major indexing services

- Maximum visibility for your research

Submit your manuscript at www.biomedcentral.com/submit
Biomed Central 